\title{
Comparative study of moss diversity in South Shetland Islands and in the Antarctic Peninsula
}

\author{
Jair Putzke ${ }^{1,2}$, Camila G Athanásio ${ }^{2}$, Margéli Pereira de Albuquerque ${ }^{2}$, Filipe C Victoria ${ }^{2 *}$ and Antonio B Pereira ${ }^{2}$
}

\begin{abstract}
Background: This paper presents a comparative study of moss diversity in three collection sites in the South Shetland Islands (King George, Elephant, and Nelson Islands) and one in the Antarctic Continent (Hope Bay, Antarctic Peninsula). In the King George, Elephant, and Nelson Islands, the collections were done in ice-free areas during the austral summers of years 1988, 1989, 1990, 1991, 1992, and 1994. In Hope Bay, the collections were done in the 2009 summer (February). All collections were deposited in the HCB (Chaves Batista Herbarium).
\end{abstract}

Findings: The King George Area is the most diverse area and the Hope Bay has the lowest diversity stats. The diversity stats for each region and the similarities between both are presented.

Conclusion: This results suggested that harder climatic conditions determine lower diversity for the bryoflora.

Keywords: Bryophyta; Flora; Ice-free area; Shannon-Weaver index

\section{Resumen}

En este trabajo se presenta un estudio comparativo de tres puntos de muestreo de musgos

en las Islas Shetland del Sur (Isla Rey Jorge, Elefante y Nelson) y el Continente Antártico (Bahía Esperanza, Península Antártica). En las Islas King George, Elefante y Nelson, se tomaron muestras en las zonas libres de hielo durante los veranos australes de años 1988, 1989, 1990, 1991, 1992 y 1994. Hope Bay, las colecciones se hicieron en el verano austral de 2009 (febrero). Todas las colecciones fueron depositadas en el herbario de HCB (Herbario Chaves Batista). Los índices de diversidad para cada región se presentan, así como la similitud entre ellos.

Palabras-clave: Bryophyta; Flora; Zonas libres de hielo; Indice de Shannon-Weaver

\section{Introduction}

The Antarctic Continent is the fifth larger continent in extension, with about 13.7 millions of $\mathrm{km}^{2}$. It is a continent of extremes, since it is the higher, colder, drier, strong winds and remote continent (Machado and Brito, 2006). In addition to these extreme climatic conditions, the UV-A and UV-B radiations are potential aspects affecting the structure and development of plants (Green et al., 2005).

Studies of plant communities in Antarctica have a very relatively short history, if compared to other parts of the world particularly tropical and temperate regions. However,

\footnotetext{
*Correspondence: filipevictoria@unipampa.edu.br

${ }^{2}$ Antarctic Plants Studies Core, Instituto Nacional de Ciência e Tecnologia Antártico de Pesquisas Ambientais-INCT-APA, Universidade Federal do Pampa - UNIPAMPA, Av. Antonio Trilha, 1847 São Gabriel, Brazil Full list of author information is available at the end of the article
}

there are areas of the Maritime Antarctic region with excellent descriptions of the vegetation, such as the South Shetlands Island (Lindsay 1971, Furmanczyk and Ochyra 1982, Hu 1998), Signy Islands (Lewis-Smith, 1972), Nelson Island (Putzke et al., 1995), and Elephant Island (Allison and Lewis-Smith, 1973, Pereira and Putzke, 1994)

The Antarctic flora is composed mainly of bryophytes and lichen species adapted to short summers and low temperatures (Putzke and Pereira 2001). Such climatic conditions inhibit the reproductive cycle, limiting the diversity and the gene pool, especially for flowering plants (Pereira and Putzke 1994). The Antarctic hair grass (Deschampsia antarctica Desv.) and the Antarctic pearlwort (Colobanthus quitensis [Kunth.] Bartl.) are the only native angiosperms growing in Antarctica but are restricted to the maritime Antarctica, which experience a shorter 


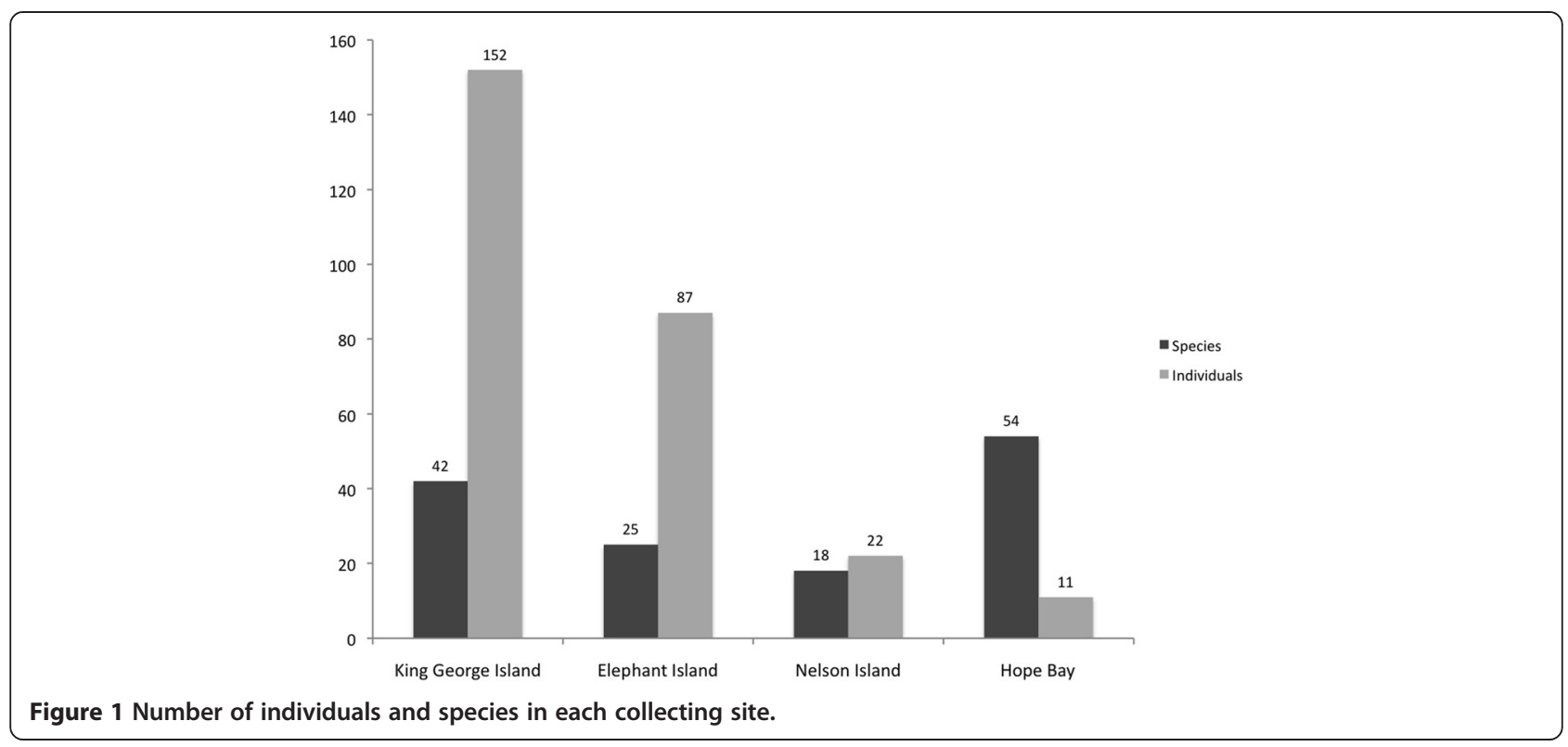

daylight period, warmer temperatures, and higher water availability in comparison to continental Antarctica.

In the continental Antarctica (2\% of the total area of Antarctica), there are observed several specific relationships to exposure of soil types, geomorphology, and water supply, so there is a positive relationship between the Antarctic flora and bird colonies (Pereira et al., 1990), where the nutrients are achieved directly from animal resources (Galimberti, 1991). Only a few plants can survive in Antarctica, and they provide a geographic distribution directly related to abiotic factors. Due to its ability to grow in such extreme environments, mosses are among the most important plants which occur in ice-free areas of Antarctica (Putzke and Pereira, 2001), although moss communities are generally considered of low complexity and species diversity (Smith, 1984).

In Antarctica, the mosses are associated to melting areas, such that they depend of water supply during the austral summer to realize photosynthesis and growing (Schaefer et al., 2004; Meick and Seppelt, 1997). Given the difficulties imposed by the environment, the mosses from Antarctica present pigments that are involved in UV radiation protection (Glime, 2007; Lovelock and Robinson, 2002), while some species are adapted to support dehydration at different levels (Robinson et al., 2000).

The moss Antarctic flora can be divided into six distinct phytogeographical elements (Ochyra, 1998) comprising a number of species for each element, as follows: Antarctic endemic distribution (11 species); Subantarctic distribution (18 species); south-temperate distribution (26 species); bipolar distribution; cosmopolitan distribution (5 species); tropical distribution (1 species). From this division, it can be observed that most of the mosses found in Antarctica have bipolar distribution, being a striking feature of the Antarctic moss flora (Ochyra et al., 2008). However, the richness and other diversity stats have not yet been widely exploited to understand the distribution of moss species in Antarctic.

In this study, the distribution of moss species among four different points from South Shetland and the Antarctic continent was compared through a review of collections, aiming to provide subsidies for the understanding of how species are distributed in the Maritime Antarctic.

\section{Methods}

The moss diversity of three island in the South Shetland archipelago (King George - $62^{\circ} 05^{\prime} 13,55^{\prime \prime} \mathrm{S}$ and $58^{\circ} 24^{\prime}$ 17, $51^{\prime \prime} \mathrm{W}$; Elephant - $61^{\circ} 11^{\prime} 51,74^{\prime \prime} \mathrm{S}$ and $55^{\circ} 17^{\prime} 56$, $37^{\prime \prime} \mathrm{W}$; and Nelson Islands - 62 $14^{\circ} 29,47^{\prime \prime} \mathrm{S}$ and $58^{\circ} 59^{\prime}$ $39,26^{\prime \prime} \mathrm{W}$ ) and one in the Antarctic Peninsula (Hope Bay - $\left.63^{\circ} 23^{\prime} 0^{\prime \prime} \mathrm{S}, 56^{\circ} 59^{\prime} 0^{\prime \prime} \mathrm{W}\right)$ were compared.

The collections were done in the ice-free areas during the austral summers of years 1988, 1989, 1990, 1991, 1992, and 1994 in the King George, Elephant, and Nelson Islands. In Hope Bay, the collections were made in the 2009 summer (February). The distribution and occurrences reported by Ochyra et al. (2008) were also checked for comparison purpose.

All collections were deposited in the HCB Herbarium (Chaves Batista Herbarium). The species were indentified according to Putzke and Pereira (2001), Ochyra (1998), and Ochyra et al. (2008). The species names follow Ochyra et al. (2008).

The data obtained about moss species growing in each sampling area were organized in a presence or absence ( 1 or 0 , respectively) and quantitative matrices (number of individual sampled) and used to describe the occurrence of each species found. These matrices were used to obtain the 
Table 1 Moss species occurrence list in each collecting site

\begin{tabular}{llll}
\hline Family/species & $\begin{array}{l}\text { King George } \\
\text { Island }\end{array}$ & $\begin{array}{l}\text { Elephant } \\
\text { Island }\end{array}$ & $\begin{array}{l}\text { Nelson Hope } \\
\text { Island Bay }\end{array}$ \\
\hline
\end{tabular}

AMBLYSTEGIACEAE

Campylium polygamum

Cratoneuropsis relaxa $\quad X$

Sanionia uncinata $\quad x$

Warnstotorfia sarmentosa $X$

ANDREAEACEAE

${\text { Andreaea } \text { acuminata }^{\mathrm{a}} \mathrm{X}}$

Andreaea depressinervis $\quad x$

Andreaea gainii

Andreaea regularis

BARTRAMIACEAE

Bartramia patens

Conostomum

magellanicum

BRACHYTHECIACEAE

Brachythecium

austrosalebrosum

Sciuro-hypnum glaciale $X$

BRYACEAE

Bryum archangelicum $X$

Bryum argenteum $X$

Bryum dichotomum $X$

Bryum orbiculatifolium $\quad X$

Bryum pseudotriquetrum $\quad X$

Pohlia cruda $X$

Pohlia drummondii $\quad X$

Pohlia nutas

Pohlia wahlenbergii $\quad X$

DICRANACEAE

Chorisodontium

aciphyllum

DITRICHACEAE

Ceratodon purpureus

Ceratodon grossiretis

Distichium capillaceum

ENCALYPTACEAE

Encalypta rhaptocarpa $X$

GRIMMIACEAE

Racomitrium sudeticum

Schistidium

amblyophyllum

Schistidium antarctici $\quad x$

Schistidium falcatum $\quad X$
Table 1 Moss species occurrence list in each collecting site (Continued)

\begin{tabular}{|c|c|c|c|c|}
\hline Schistidium rivulare & $x$ & & $x$ & \\
\hline \multicolumn{5}{|l|}{ HYPNACEAE } \\
\hline Hypnum revolutum & $x$ & & & \\
\hline \multicolumn{5}{|l|}{ ORTHOTRICHACEAE } \\
\hline Muelleriella crassifolia & & $x$ & & \\
\hline \multicolumn{5}{|l|}{ PLAGIOTHECIACEAE } \\
\hline $\begin{array}{l}\text { Plagiothecium } \\
\text { orthocarpum }\end{array}$ & $x$ & & & \\
\hline \multicolumn{5}{|l|}{ POLYTRICACEAE } \\
\hline Polytrichum alpinum & $x$ & $x$ & $x$ & \\
\hline Polytrichum juniperinum & $x$ & $x$ & $x$ & \\
\hline Polytrichum piliferum & $x$ & & $x$ & \\
\hline Polytrichum strictum & & & & $x$ \\
\hline \multicolumn{5}{|l|}{ POTTIACEAE } \\
\hline Hennediella antarctica & $x$ & $x$ & & $x$ \\
\hline Hennediella heimii & $x$ & $x$ & $x$ & \\
\hline Syntrichia filaris & $x$ & & $x$ & \\
\hline Syntrichia magellanica & $x$ & & & $x$ \\
\hline Syntrichia saxicola & $x$ & $x$ & & $x$ \\
\hline \multicolumn{5}{|l|}{ SELIGERACEAE } \\
\hline Hymenoloma antarcticum & $x$ & & & \\
\hline $\begin{array}{l}\text { Hymenoloma } \\
\text { grimmiaceum }\end{array}$ & $x$ & $x$ & & \\
\hline
\end{tabular}

${ }^{\mathrm{a}}$ Found only by Putzke and Pereira (2001).

diversity stats, where we used Shannon-Weaver diversity index $\left(\mathrm{H}^{\prime}\right)$ and the Jaccard's similarity coefficient $\left(\mathrm{J}^{\prime}\right)$ with help of the PAST statistic program version 1.91 to evaluate the richness and the similarity of the species.

\section{Findings}

Richness data

In the taxonomical review, 46 species were identified, belonging to 23 genera and 15 families. These 46 taxa correspond to $41 \%$ of the species that were reported to Antarctica (Ochyra, et al., 2008).

From 276 samples reviewed, 315 moss occurrences were observed in the four sampled areas (Figure 1). From these, 152 occurred in King George Island, 87 in Elephant Island, 22 in Nelson Island, and 54 in Hope Bay. King George Island also has the greater number of species (42), followed by Elephant (25) and Nelson (18). Hope Bay has the lowest species number of all studied sites (11). The data of species occurrence in each collecting site are listed in Table 1.

Out of 15 families found, Bryaceae (10 species in 2 genera) was the most common, followed by Pottiaceae and Grimmiaceae (5 species and 2 genera both). Amblystegiaceae was the family with the higher number of genera observed (4). 


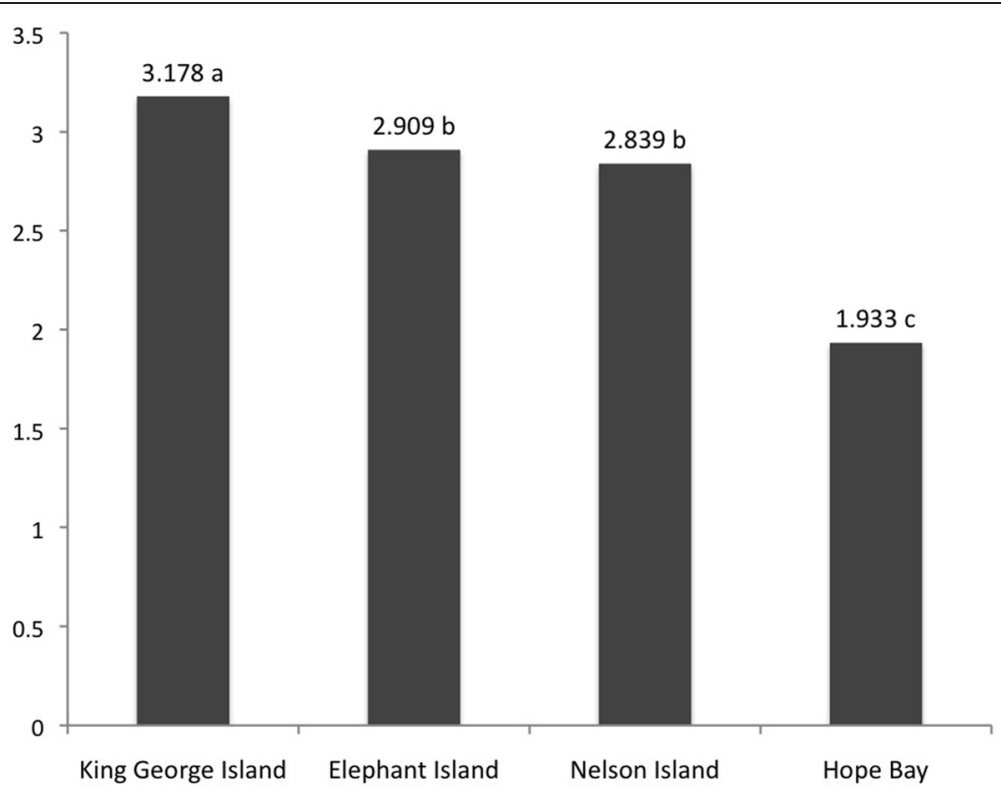

Figure 2 Shannon diversity index to each collecting point. Distinct letter means statistical differences found in the sampling.

Many moss species were found associated to other species. In the Hope Bay region, for example, Ceratodon purpureus - Polytrichum strictum was the most frequently association found. Associations between this genus and Andreaea depressinervis - Andreaea gainii were also found, as well as between Andreaea depressinervis - Ceratodon purpureus and Andreaea depressinervis - Sanionia uncinata.

Andreae acumminata Cardot. was recognized in Antarctica by Putzke and Pereira (2001) for Nelson Island only. Ochyra et al. (2008) exclude this species

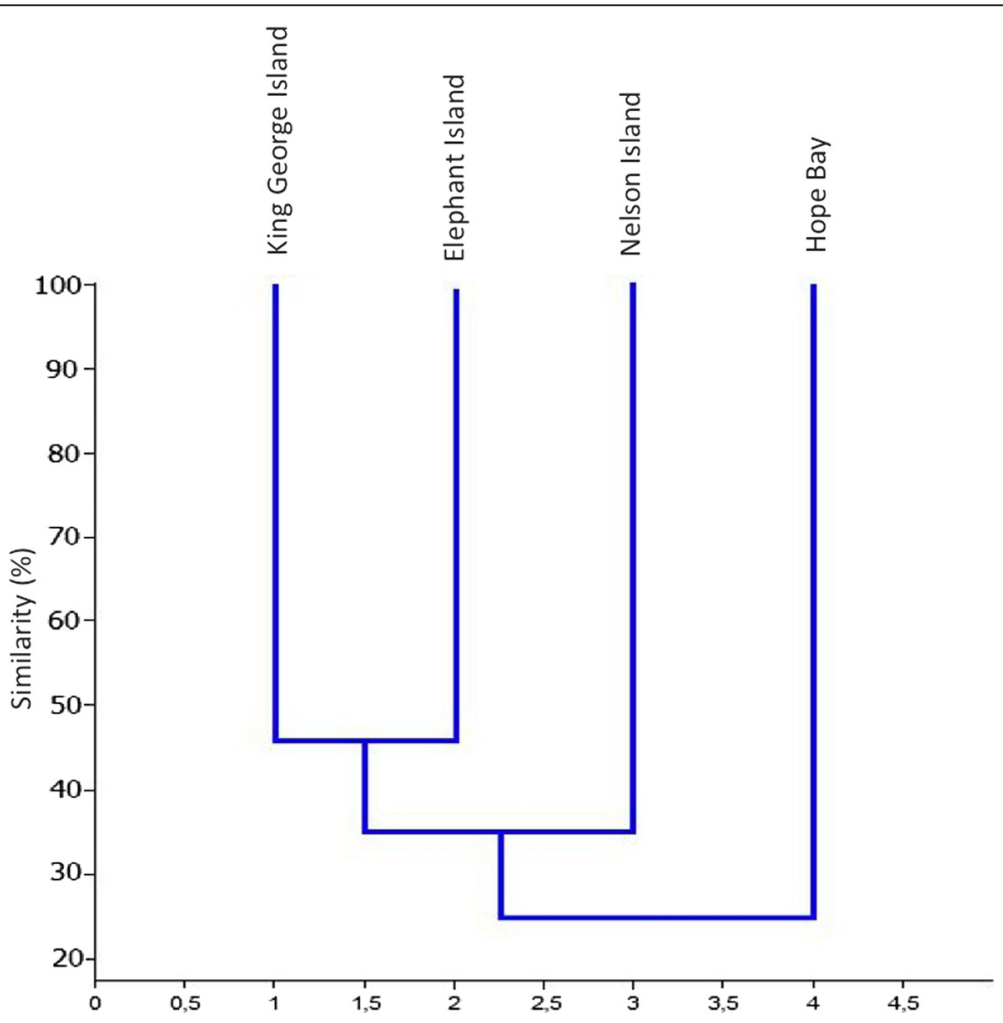

Figure 3 Clustering analysis of the Jaccard similarity coefficient to each collecting site. 
from moss flora of Antarctica but without reviewing the material under voucher 30292 (HBC); thus, we maintain this species to the moss flora of Antarctica, since the characteristics of the sample analyzed are in accordance to the diagnostic features of this species.

\section{Diversity and similarity stats}

The Shannon-Weaver index indicated that King George Island is the most diverse area $\left(\mathrm{H}^{\prime}=3,178\right)$, followed by Elephant Island $\left(\mathrm{H}^{\prime}=2,909\right)$ and Nelson Island $\left(H^{\prime}=2,839\right)$. Hope Bay presented the lowest result $\left(\mathrm{H}^{\prime}=1,933\right)$ (Figure 2).

The Shannon-Weaver index, comparing Elephant and Nelson Islands, brought no significant differences in the diversity of both islands $\left(\mathrm{H}^{\prime}=2,909\right.$ and $\mathrm{H}^{\prime}=2,839$, respectively).

Despite this, the number of species is different in each Island (Elephant $=25$, Nelson $=18$ species), as well the sample number (Elephant $=87$, Nelson $=22$ individuals), suggesting differences in moss communities in these islands. The other collecting sites presented statistically significant differences.

Hope Bay shows the lowest richness, probably because of the harder climate conditions found in the area. In addition, information about species richness can be incomplete because of the difficulty in collecting data in this point. Sanionia uncinata has the highest occurrence such that the species was found in all areas studied. Ceratodon purpureus was the most common species in Hope Bay.

The similarity calculated by the Jaccard coefficient indicates a high similarity between King George and Elephant Island, followed by Nelson Island and Hope Bay (Figure 3 ).

\section{Discussion}

The highest species number and the individual occurrence for each species in King George Island are probably associated to the climatic conditions (warmer, humid, and low wind incidences). It cannot be excluded due to the fact that the location of the Brazilian Base in this island allows a higher collection effort (Pereira and Putzke, 1994; Pereira et al., 2008; Peat et al., 2007).

The richness and the Shannon-Weaver index pointed King George Island as the most diverse. Victoria and Pereira (2007) showed that the highest temperatures and weak winds were found in the Admiralty Bay, generating a distinct microclimate in this area, in comparison to the rest of the island, and thus can be reflecting in higher plant diversity in this area. The Elephant and Nelson Island, despite the differences in the individuals sampled, are both often related as islands with a moderate moss diversity, where no specific occurrences were found (Putzke et al, 1998; Pereira and Putzke 1994), unlike
King George Island that has a known occurrence of endemic species cited in the literature (Ochyra, 1998). On the other hand, the moss flora from King George and Elephant Island are found to have higher similarities (Figure 3), even though Nelson Island is nearer to King George Island. These similarities can be explained by the similarities in the relief of the ice-free areas of both islands, allowing the existence of same niches for the occurrence of similar growth forms, which are usually occupied from the same taxa (Victoria et al., 2009).

The lowest values for richness and diversity were observed in Hope Bay. This supports the direct relationship between latitude and diversity in Polar Regions, as discussed by Peat et al. (2007). The similarity data also support this hypothesis, such that the community structure is closer within South Shetlands Island than between each island and Hope Bay (Figure 3).

Although this analysis suggested that harder climatic conditions determine lower diversity for the bryoflora, further efforts in equally sampling in all sites are needed in order to evaluate the impact of sampling strategies in these results.

\section{Competing interests}

The authors declare that they have no competing interests.

\section{Authors' contributions}

JP carried out all field studies, including the sampling and the diversity evaluation. CGA carried out the laboratory studies. FCV participate in diversity stats analysis. MPA participate in diversity stats analysis. ABP conceived the study, and participated in its design and coordination. All authors read and approved the final manuscript.

\section{Acknowledgements}

This work was supported by the Brazilian Antarctic Program through the CNPq (process no. 574018/2008), FAPERJ (process no. E-26/170.023/2008), Ministry of Environment - MMA, and Ministry of Science and Technology - MCT and CIRM.

\section{Author details}

${ }^{1}$ Universidade de Santa Cruz do Sul - UNISC, Avenida Independência, 2293 Santa Cruz do Sul, Brazil. ${ }^{2}$ Antarctic Plants Studies Core, Instituto Nacional de Ciência e Tecnologia Antártico de Pesquisas Ambientais-INCT-APA, Universidade Federal do Pampa - UNIPAMPA, Av. Antonio Trilha, 1847 São Gabriel, Brazil.

Received: 13 February 2014 Accepted: 22 December 2014

Published online: 19 March 2015

\section{References}

Allison JS, Lewis-Smith RI (1973) The vegetation of Elephant Island, South Shetland Islands. British Antarctic Survey Bulletin, v. 33-34, pp 185-212 Furmanczyk K, Ochyra R (1982) Plant communities of the Admiralty Bay region (King George Island, South Shetland Island, Antarctic). I Jasnorzewski Gardens. Polish Polar Research 3:25-39

Galimberti D (1991) Antarctica an introductory guide. Zagier \& Urruty Publications, Florida

Glime JM (2007) Bryophyte ecology. Volume 1. Physiological ecology. Ebook sponsored by Michigan Technological University and the International Association of Bryologists. Accessed on 12-12-2013 at http://www.bryoecol.mtu.edu/ Green TGA, Kulle D, Pannewitz S, Sancho LG, Schroeter B (2005) UV-A protection in mosses growing in continental Antarctica. Polar Biol 28(11):822-827 
Hu SS (1998) Moss communities types and species diversity of Southern Fields Peninsula (King George Island, South Shetland Islands) Antarctica. Journal of Hattori Botany Laboratory, v. 84, pp 187-198

Lewis-Smith RI (1972) Vegetation of the South Orkney Island with particular references to Signy Island. British Antarctic Survey Bulletin, v. 33/34, pp 89-122

Lindsay DC (1971) Vegetation of the South Shetland Islands. British Antartic Survey, v. n25, pp 59-83

Lovelock CE, Robinson SA (2002) Surface reflectance properties of Antarctic moss and their relationship to plant species, pigment composition and photosynthetic function. Plant Cell Environ 25:1239-1250

Machado MCS, Brito T (2006) Antártica: Ensino Fundamental e Ensino Médio. Ministério da Educação, Secretaria da Educação Básica, Brasília

Meick DR, Seppelt RD (1997) Vegetation patterns in relation to climatic and endogenous changes in Wilkes Land, Continental Antarctica. J Ecol 85:43-56

Ochyra R (1998) The moss flora of King George Island Antarctica. Academy of Sciences, Cracow

Ochyra R, Lewis Smith Rl, Bednarek Ochyra H (2008) The illustrated moss flora of Antarctica. Cambridge University Press, Cambridge, p 685

Peat HJ, Clarke A, Convey P (2007) Diversity and biogeography of the Antarctic flora. J Biogeogr 34:132-146

Pereira AB, Putzke J (1994) Floristic composition of Stinker Point, Elephant Island, Antarctica. Korean J Polar Res 5(2):37-47

Pereira AB, Putzke J, Sander M (1990) Plants utilized by Larus dominicanus Lichtenstein (1823) for nest building at the South Shetland Island, Antarctica. Pesqui Antártica Bras 2(1):79-85

Pereira AB, Putzke MTL, Putzke J (2008) Biological communities of Keller Peninsula, King George Island - Antarctica. Caderno Pesquisa Série Biol 20(3):63-74

Putzke J, Pereira AB (2001) The Antarctic mosses with special reference to the South Shetland Islands. (ed) Ulbra, Canoas

Putzke J, Pereira AB, Putzke MTL (1998) Moss communities of rip point in Northern Island, South Shetland Islands, Antarctica. Pesqui Antártica Bras 3(1):104-115

Putzke J, Putzke MTL, Pereira AB (1995) Moss communities of Rip Point in Northern Nelson Island, South Shetland Islands, Antarctica. Polar Biology, v. 2, pp 20-40

Robinson S, Wasley J, Popp M, Lovelock CE (2000) Desiccation tolerance of three moss species from continental Antarctica. Aust J Plant Physiol 27:379-388

Schaefer CEGR, Simas FBN, Albuquerque-Filho MR, Michel RFM, Viana J, Tatur HM (2004) Fosfatização: processo de formação de solos na Baía do Almirantado e implicações ambientais. In: Schaefer CN, Francelino MR, Simas FNB, Albuquerque F, De MR (ed) Ecossistemas Costeiros e Monitoramento Ambiental da Antártica Marítima: Baía do Almirantado, Ilha Rei George. NEPUT-Departamento de Solos, Viçosa, pp 47-58

Smith RIL (1984) Terrestrial plant biology. In: Laws RM (ed) Antarctic ecology, vol 1. Academic Press, London

Victoria FC, Pereira AB (2007) Índice de valor ecológico (IES) como ferramenta para estudos fitossociológicos e conservação das espécies de musgos na Baia do Almirantado, Ilha Rei George, Antártica Marítima. Oecologia Brasiliensis 11(1):50-55

Victoria FC, Costa DP, Pereira AB (2009) Life-forms of moss species in defrosting areas of King George Island, South Shetland Islands, Antarctica. Biosci J 25(3):151-160

\section{Submit your manuscript to a SpringerOpen ${ }^{\circ}$ journal and benefit from:}

- Convenient online submission

- Rigorous peer review

- Immediate publication on acceptance

- Open access: articles freely available online

- High visibility within the field

- Retaining the copyright to your article

Submit your next manuscript at $>$ springeropen.com 